\title{
Increase in E-selectin expression in umbilical vein endothelial cells by anticancer drugs and inhibition by cimetidine
}

\author{
JIN KAWASE ${ }^{1}$, SOJI OZAWA ${ }^{1}$, KENICHI KOBAYASHI ${ }^{1}$, YOSHIHIRO IMAEDA ${ }^{1}$, \\ SHUNJI UMEMOTO ${ }^{1}$, SUMIO MATSUMOTO ${ }^{2}$ and MASAKAZU UEDA ${ }^{3}$
}

\author{
${ }^{1}$ Department of General and Gastrointestinal Surgery, School of Medicine, Fujita Health University, 3-6-10 Otobashi, \\ Nakagawa-ku, Nagoya, Aichi 454-8509; ${ }^{2}$ Department of Surgery, National Hospital Organization Tokyo Medical Center, \\ 2-5-1 Higashigaoka, Meguro-ku, Tokyo 152-8902; ${ }^{3}$ Department of Surgery, School of Medicine, \\ Keio University, 35 Shinanomachi, Shinjuku-ku, Tokyo 160-8582, Japan
}

Received June 26, 2009; Accepted July 27, 2009

DOI: 10.3892/or_00000567

\begin{abstract}
E-selectin is expressed on the surfaces of stimulated vascular endothelial cells and is sometimes involved in cancer cell metastasis. The $\mathrm{H}_{2}$-receptor antagonist cimetidine inhibits the increase in E-selectin expression on vascular endothelial cells that is induced by interleukin-1ß (IL-1ß) and cimetidine. It also inhibits the adhesion of sialyl-Lewis-antigen-positive cancer cells to vascular endothelial cells, ultimately inhibiting hematogenous metastasis. Anticancer drugs are essential to cancer therapy, but whether they can alter the expression of E-selectin in vascular endothelial cells remains unclear. Whether cimetidine inhibits the expression of E-selectin in the same manner in the presence or absence of anticancer drugs also remains unknown. Human umbilical vein endothelial cells were cultured with 5-fluorouracil (5-FU), doxorubicin (DXR), cisplatin (CDDP), or IL-1ß and with or without cimetidine. The expression of E-selectin at the mRNA and protein levels was then determined using quantitative reverse transcriptionpolymerase chain reaction and immunohistochemical staining, respectively. The E-selectin mRNA level increased in cells exposed to 5-FU, DXR, or CDDP, but the addition of cimetidine had no effect on the E-selectin mRNA level. The expression of E-selectin protein was also significantly higher after the addition of 5-FU, DXR, or CDDP, compared with that of a negative control. However, when cimetidine was added prior to the addition of 5-FU, DXR, or CDDP, the expression of E-selectin was significantly suppressed. Thus, cimetidine significantly inhibited the expression of E-selectin at the
\end{abstract}

Correspondence to: Professor Soji Ozawa, Department of General and Gastrointestinal Surgery, School of Medicine, Fujita Health University, 3-6-10 Otobashi, Nakagawa-ku, Nagoya, Aichi 454-8509, Japan

E-mail: sozawa@fujita-hu.ac.jp

Key words: E-selectin, 5-fluorouracil, doxorubicin, cisplatin, cimetidine protein level without affecting its expression at the mRNA level in cells treated with anticancer drugs. In conclusion, anticancer drugs increased the expression of E-selectin and this increase was inhibited by cimetidine. These findings suggest that the administration of cimetidine during treatment with anticancer drugs might be useful for preventing metastasis.

\section{Introduction}

E-selectin is a heavily glycosylated transmembrane protein of which the relative molecular weight is $64 \mathrm{kDa}$. It is synthesized de novo by endothelial cells in response to cytokines including IL-1, lipopolysaccharide, TNF- $\alpha$, or G-CSF and is sometimes involved in cancer cell metastasis (1). We have already reported finding that the $\mathrm{H}_{2}$-receptor antagonist cimetidine inhibits the increase in expression of E-selectin on human umbilical vein endothelial cells (HUVECs) that is induced by interleukin-1ß (IL-1ß) and that cimetidine inhibits the adhesion of sialyl-Lewis-antigen-positive tumor cells to vascular endothelial cells and ultimately inhibits hematogenous metastasis (2-4). An inhibitory effect of cimetidine on metastasis has been reported previously in colorectal cancer (5-9) and therapeutic efficacy has been reported in gastric cancer (10), renal cell carcinoma (11) and malignant melanoma (12). Cimetidine has been thoroughly investigated with respect to the mechanism of its inhibition of gastric acid secretion and it is very interesting that its above-described actions on cancer has still not been adequately elucidated.

Anticancer drugs, are essential to cancer therapy, but it is unclear whether they alter the expression of E-selectin on vascular endothelial cells. If anticancer drugs inhibit Eselectin expression, they could be expected to have an inhibitory effect on metastasis, however, if the opposite is true, and they increase E-selectin expression, then there would be apprehension that they would promote metastasis. If E-selectin expression were altered by anticancer drugs, it is unknown whether cimetidine would inhibit expression of E-selectin in the same manner as in the absence of anticancer drugs. In the present study, we therefore investigated whether anticancer drugs alter expression of E-selectin on vascular endothelial cells and how cimetidine would modify the change 
caused by anticancer drugs at both the mRNA level and the protein level.

\section{Materials and methods}

HUVECs (Sanko Junyaku, Tokyo, Japan) from a single donor were used at 4 to 9 passages. The liquid medium used to culture the HUVECs was Endothelial Cell Basal Medium-2/EBM-2 (Bullet Kit) to which a growth supplement (hydrocortisone, hFGF-b, VEGF, R3-IGF-1, ascorbic acid, heparin, FBS, hEGF, and GA-1000) (Sanko Junyaku) had been added. Cell culture flasks with $25 \mathrm{~cm}^{2}$ canted neck and vented cap (Becton-Dickinson, NJ, USA) were used for ordinary cell culture. Lab-Tek II chamber slides (2-well, Nalge Nunc International, Tokyo, Japan) were used for cell culture for immunostaining.

A FastPure RNA kit (Takara Bio Inc., Shiga, Japan) was used to extract total RNA and a One Step SYBR ${ }^{\circledR}$ PrimeScript RT-PCR kit II (Takara Bio Inc.) was used for real-time RT-PCR. The sequence products (Takara Bio Inc.) shown in Table I were used as the primers for the E-selectin gene (HA080612) and the $\beta$-actin gene (HA067803) (13) and a Thermal Cycler Dice ${ }^{\circledR}$ Real-Time System (Takara Bio Inc.) was employed for the RT-PCR. CD62E (E-selectin) mouse monoclonal antibody (Novocastra Laboratories Ltd., Newcastle upon Tyne, UK) was the primary antibody for immunohistochemical staining and the Dako CSA System (Dako Japan, Tokyo, Japan) was the staining kit.

The drugs were 5-fluorouracil (5-FU; Kyowa Hakko Kirin, Tokyo, Japan), doxorubicin hydrochloride (DXR; Kyowa Hakko Kirin, Tokyo, Japan), cisplatin (CDDP; Nippon Kayaku, Tokyo, Japan), interleukin-1ß (IL-1ß) (Roche, Mannheim, Germany) and cimetidine (Dainippon Sumitomo Pharma, Osaka, Japan).

Quantitative determination of E-selectin mRNA by RT-PCR. The HUVECs were grown in the cell culture flasks to subconfluence and the drugs were added to the HUVEC culture fluid. 5-FU was added to final concentrations of 1, 2, 5, 10, 20 and $50 \mu \mathrm{g} / \mathrm{ml}$, DXR to final concentrations of 0.01 , $0.025,0.05,0.1,0.2$ and $0.5 \mu \mathrm{g} / \mathrm{ml}$, and CDDP to final concentrations of $0.05,0.10,0.25,0.5,1.0$ and $2.5 \mu \mathrm{g} / \mathrm{ml}$ and culture was continued for $48 \mathrm{~h}$. IL- $1 \beta$ was added to a concentration of $10 \mathrm{ng} / \mathrm{ml}$ and culture was continued for $6 \mathrm{~h}$. Phosphate-buffered saline (PBS) was added as a control. Cimetidine was added to the culture fluid to a final concentration of $10^{-6} \mathrm{M} 2 \mathrm{~h}$ before adding each of the drugs.

Quantitative RT-PCR was carried out as described below. HUVECs were freed from the flasks by treating them with trypsin and the cells were collected by centrifugation. Total RNAs were extracted with the FastPure RNA kit and after measuring their concentrations, they were adjusted to $5 \mathrm{ng} / \mu 1$. The extraction conditions described in the kit protocol were used. The reaction solution was prepared by using the One Step SYBR PrimeScript RT-PCR kit II and the levels of expression of the E-selectin gene and the $B$-actin gene were measured with the Thermal Cycler Dice Real-Time System. The reaction solution and reaction conditions were those described in the kit protocol. The levels of expression in each of the samples were determined from the standard curves for
Table I. Sequences of the PCR primers.

\section{Sequence}

\begin{tabular}{ll}
$\begin{array}{l}\text { E-selectin } \\
\text { Forward primer }\end{array}$ & 5'-cactcaagggcagtggacaca-3' \\
Reverse primer & 5'-cagctggacccataacggaaac-3' \\
B-actin & \\
Forward primer & 5'-tggcacccagcacaatgaa-3' \\
Reverse primer & 5'-ctaagtcatagtccgcctagaagca-3' \\
\hline
\end{tabular}

the E-selectin gene and the $\beta$-actin gene and the expression ratios of each sample relative to the control were calculated.

Analysis of E-selectin expression by immunohistochemical staining. HUVECs were cultured to subconfluence on Lab-Tek II chamber slides and each of the drugs was added to the HUVEC culture fluid. 5-FU was added to a final concentration of $1 \mu \mathrm{g} / \mathrm{ml}$, DXR to a final concentration of $0.025 \mu \mathrm{g} / \mathrm{ml}$ and CDDP to a final concentration of $2.5 \mu \mathrm{g} / \mathrm{ml}$ and the cells were cultured for $48 \mathrm{~h}$. IL-1ß was added to a concentration of $10 \mathrm{ng} / \mathrm{ml}$ and the cells were cultured for $6 \mathrm{~h}$. PBS was added as a control. Cimetidine was added to the culture fluid to a final concentration of $10^{-6} \mathrm{M} 2 \mathrm{~h}$ before adding each of the drugs.

Immunohistochemical staining was performed as described below. The cells were fixed by exposing the chamber slides to paraformaldehyde for $10 \mathrm{~min}$ at $4^{\circ} \mathrm{C}$ and after washing with PBS for 5 min twice, they were allowed to dry in air and were immunostained. The primary antibody was used at a 1:100 dilution and it was allowed to react for $1 \mathrm{~h}$ at room temperature. The staining kit was used according to the recommended protocol. Nuclear staining was performed with Mayer's hematoxylin. Cells whose cytoplasm and cell membrane stained brown immunohistochemically were recorded as positive. The numbers of positive cells in 10 fields viewed through a 40-power objective lens were counted and the positive rate was calculated.

The Mann-Whitney U test was used to perform the statistical analysis and P-value $<0.05$ was considered a statistically significant difference.

\section{Results}

Quantitative determination of E-selectin mRNA by RT-PCR. When exposed to 5-FU, E-selectin expression increased concentration-dependently (Fig. 1). When exposed to DXR, E-selectin expression peaked at $0.025 \mu \mathrm{g} / \mathrm{ml}$ and then decreased as the concentration increased (Fig. 2). With CDDP, E-selectin expression increased concentrationdependently, the same as with 5-FU (Fig. 3). We then investigated the effect of cimetidine at the two concentrations of each drug (5-FU: low $1 \mu \mathrm{g} / \mathrm{ml}$, high $10 \mu \mathrm{g} / \mathrm{ml}$; DXR: low $0.01 \mu \mathrm{g} / \mathrm{ml}$, high $0.1 \mu \mathrm{g} / \mathrm{ml}$; CDDP: low $0.05 \mu \mathrm{g} / \mathrm{ml}$, high 0.5 $\mu \mathrm{g} / \mathrm{ml}$ ) as observed in the experiments described above. No differences in E-selectin expression were observed according to whether cimetidine had been added or not (Fig. 4). 


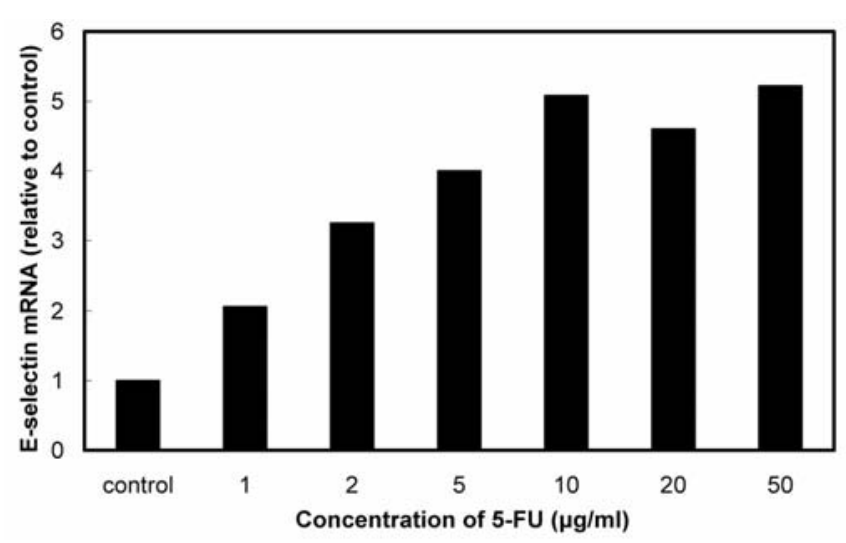

Figure 1. Effect of 5-FU on expression of E-selectin mRNA.

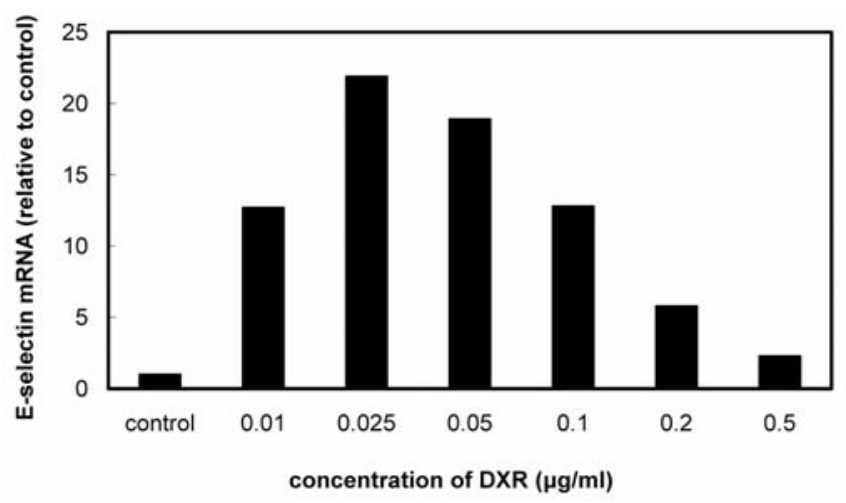

Figure 2. Effect of DXR on expression of E-selectin mRNA.

Analysis of E-selectin expression by immunohistochemical staining. The E-selectin expression rate in the negative control to which PBS had been added was $0 \%$ and the expression rate was also $0 \%$ when cimetidine alone was added. E-selectin expression was observed in all of the HUVECs in the positive control to which IL-1ß had been added and the expression rate was $100 \%$. The concentrations of the anticancer drugs were set at the concentrations at which the strongest expression of mRNA was obtained by RT-PCR.

E-selectin expression was observed when each of three drugs, i.e., 5-FU $(1 \mu \mathrm{g} / \mathrm{ml})$, DXR $(0.025 \mu \mathrm{g} / \mathrm{ml})$ and CDDP $(2.5 \mu \mathrm{g} / \mathrm{ml})$ were added. Under these conditions expression was strongest with IL-1ß and then, in decreasing order, with 5-FU and with DXR and CDDP (Fig. 5). The E-selectin expression rates when 5-FU, DXR and CDDP were added were $7,69.3$ and $74.3 \%$, respectively and expression with anticancer drug had significantly increased in comparison with the negative control $(\mathrm{P}=0.002, \mathrm{P}=0.0022$ and $\mathrm{P}=0.0047$, respectively) (Fig. 6).

When cimetidine was added before adding IL-1ß, the Eselectin expression rate was significantly suppressed, from 100 to $5 \%$ ( $\mathrm{P}=0.0002)$. Similarly, previous addition of cimetidine attenuated E-selectin expression in response to 5-FU, DXR and CDDP (Fig. 5). When cimetidine was added in advance, E-selectin expression significantly decreased from 7 to $0 \%$ after addition of $5-\mathrm{FU}(\mathrm{P}=0.0002)$, from 69.3 to $17.4 \%$ after addition of $\mathrm{DXR}(\mathrm{P}=0.0253)$ and from 74.3 to $11.2 \%$ after addition of CDDP $(\mathrm{P}=0.0209)$ (Fig. 6).

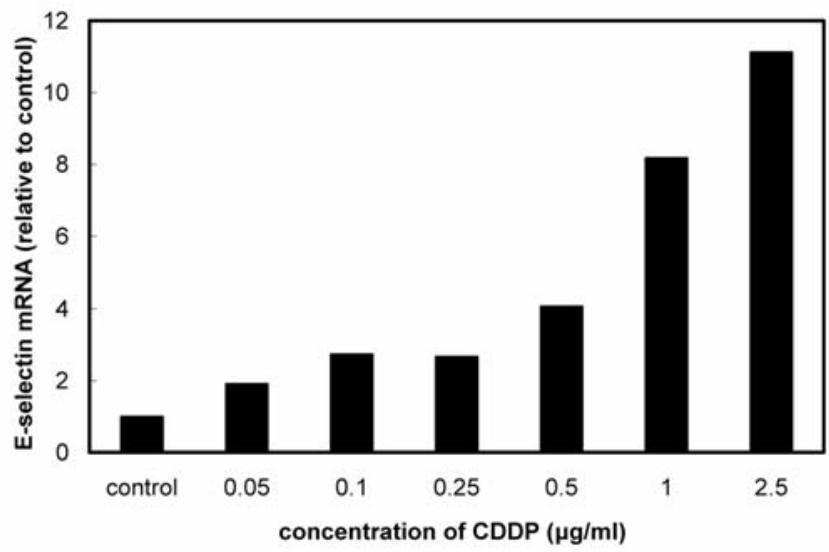

Figure 3. Effect of CDDP on expression of E-selectin mRNA.

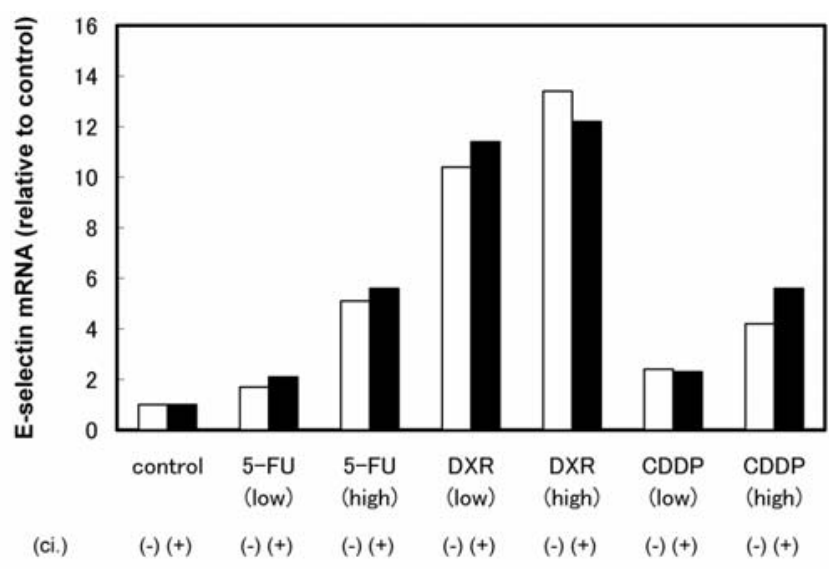

Figure 4. Effect of each of the anticancer drugs on expression of E-selectin mRNA and the effect of cimetidine. Measurements were made at two concentrations of each anticancer drug (5-FU: low $1 \mu \mathrm{g} / \mathrm{ml}$, high $10 \mu \mathrm{g} / \mathrm{ml}$; DXR: low $0.01 \mu \mathrm{g} / \mathrm{ml}$, high $0.1 \mu \mathrm{g} / \mathrm{ml}$; CDDP: low $0.05 \mu \mathrm{g} / \mathrm{ml}$, high $0.5 \mu \mathrm{g} / \mathrm{ml}$ ).

\section{Discussion}

The Liotta's hypothesis is currently being widely used to explain the establishment of hematogenous metastases by cancer cells (14). It is thought that if inhibition is possible at any stage at all, the establishment of hematogenous cancer metastases can be prevented $(15,16)$. E-selectin is a protein that is synthesized when vascular endothelial cells are exposed to stimulation by pro-inflammatory cytokines, etc., and expression on the cell surface peaks 4-6 h after stimulation. Some of it is internalized and degraded within the cells and some is said to undergo a process in which it is cleaved, released into the blood and disappears $24 \mathrm{~h}$ later and is involved in cancer cell metastasis. In order for cancer cells that have entered the bloodstream to a establish metastasis they must adhere to peripheral vascular endothelial cells.

In this study, we therefore focused our attention on Eselectin, which is closely involved in cancer cell adhesion to peripheral vascular endothelial cells and investigated the effect of anticancer drugs, which are essential to the treatment of cancer metastasis, on expression of E-selectin. The results showed that the anticancer drugs increased E-selectin expression at both the mRNA level and protein level, and that 


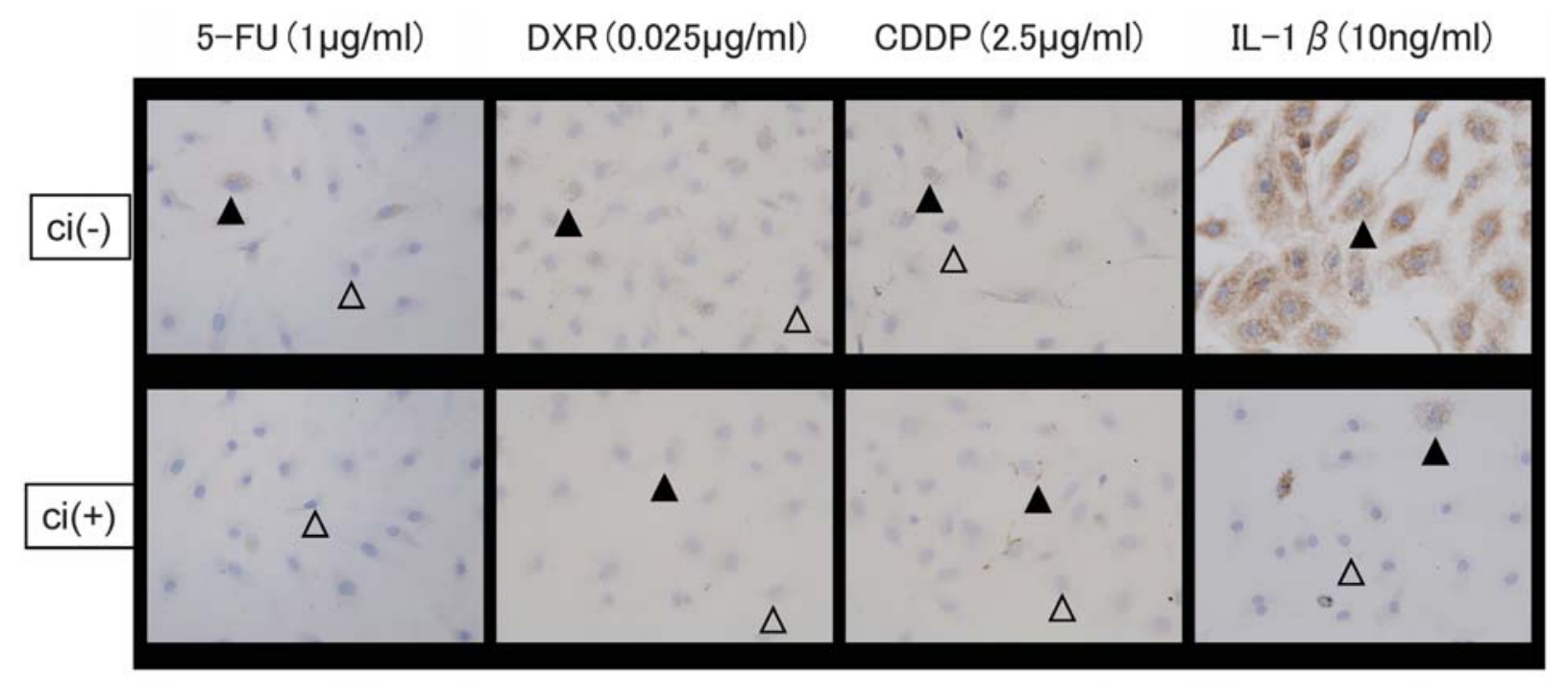

$\boldsymbol{\Delta}$ : positive cell, $\Delta$ : negative cell

Figure 5. Immunohistochemical staining. Expression of E-selectin on HUVECs was observed in response to all of the anticancer drugs (5-FU: $1 \mu \mathrm{g} / \mathrm{ml}$; DXR: $0.025 \mu \mathrm{g} / \mathrm{ml}$; CDDP: $2.5 \mu \mathrm{g} / \mathrm{ml}$ ) and expression of E-selectin was attenuated by prior treatment with cimetidine (ci, cimetidine).

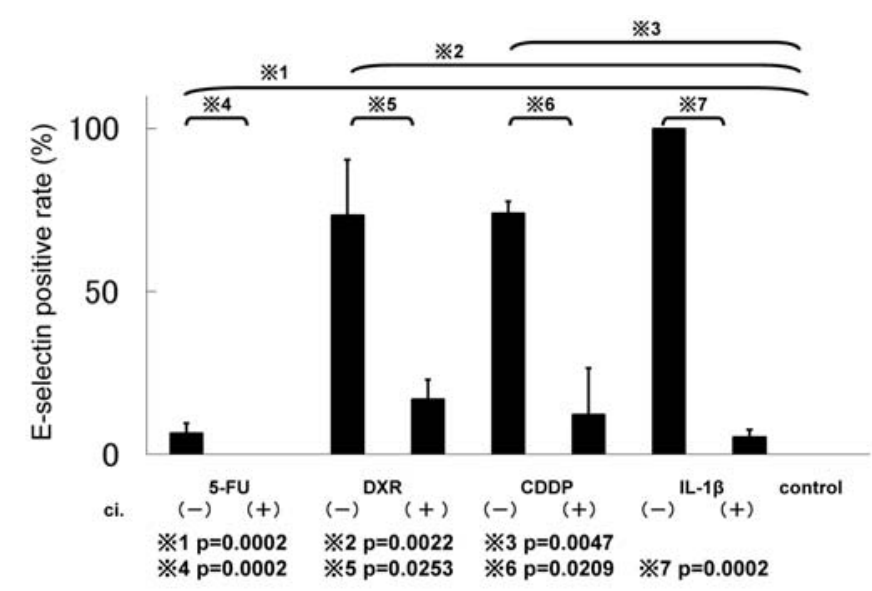

Figure 6. Positive rates for E-selectin on HUVECs according to the results of immunohistochemical staining.

cimetidine, which has a metastasis-inhibiting effect, inhibited the increase in expression of E-selectin protein by the anticancer drugs, but had no effect at the mRNA level.

The mechanism by which the anticancer drugs increased expression of E-selectin, the same as by IL- $1 \beta$ and TNF- $\alpha$, is inferred to be induction of E-selectin expression mediated by the transcription factor NFKB. With DXR, the level of mRNA expression peaked at $0.025 \mu \mathrm{g} / \mathrm{ml}$ and declined at higher concentrations and that is thought to have been because RNA synthesis became impaired as a result of the cytotoxicity of DXR for HUVECs. It was thought that when the anticancer drug in the culture fluid reached high concentrations, it induced HUVEC cell death, and all protein expression, including that of E-selectin, decreased.

Cimetidine significantly inhibited expression of E-selectin at the protein level without affecting its expression at the mRNA level. The mechanism is inferred to be that, in the same way as the mechanism that inhibits stimulation by IL-1ß, cimetidine inhibits a step after transcription, in other words, is involved in inhibiting E-selectin protein synthesis or the mechanism of E-selectin translocation to the cell surface (4). The mechanism by which concomitant use of cimetidine during adjuvant chemotherapy improves the outcome of colorectal cancer with a high level of expression of sialyl-Lewis-antigen has not been elucidated (2), but in the present study it appeared likely to be because E-selectin expression in response to the anticancer drugs was inhibited and adhesion to vascular endothelial cells by the cancer cells in the circulating blood was inhibited.

Cancer cell adhesion to vascular endothelial cells has been confirmed to be mediated by E-selectin (17-19). A complete response is not obtained in every case treated with anticancer drugs, because some cancer cells are resistant to anticancer drugs and survive. The results suggested that cimetidine may inhibit adhesion to vascular endothelial cells by cancer cells that are resistant to anticancer drugs, invade blood vessels, are released into the blood stream, and whose E-selectin expression has been increased by anticancer drugs, and ultimately inhibits metastasis. Thus, concomitantly using cimetidine to prevent metastasis when treating with anticancer drugs in every area appears to be significant.

The conclusions of this study were that the anticancer drugs increased E-selectin expression and that the increases in E-selectin expression by the anticancer drugs were inhibited by cimetidine, suggesting that administering cimetidine when treating with anticancer drugs may be useful as a means of preventing metastasis.

\section{Acknowledgements}

We thank Ms. Miho Hakukawa for her great contribution to the conduct of this study and the preparation of the manuscript. 


\section{References}

1. Steven RB, Jacyln DG, Leyla D and Charles JD: Targeting selectins and selectin ligands in inflammation and cancer. Expert Opin Ther Targets 11: 1473-1491, 2007.

2. Matsumoto S: Cimetidine and survival with colorectal cancer. Lancet 346: 115, 1995.

3. Matsumoto S, Imaeda Y, Umemoto S, Kobayashi K, Suzuki H and Okamoto T: Cimetidine increases survival of colorectal cancer patients with high levels of sialyl Lewis-X and sialyl Lewis-A epitope expression on tumor cells. Br J Cancer 86: 161-167, 2002.

4. Kobayashi K, Matsumoto S, Morishima T, Kawabe T and Okamoto T: Cimetidine inhibits cancer cell adhesion to endothelial cells and prevents metastasis by blocking E-selectin expression. Cancer Res 60: 3978-3984, 2000.

5. Adams WJ and Morris DL: Short-course cimetidine and survival with colorectal cancer. Lancet 344: 1768-1769, 1994.

6. Adams W and Morris D: Cimetidine and colorectal cancer. Dis Colon Rectum 39: 111-112, 1996.

7. Morris DL and Adams WJ: Cimetidine and colorectal cancer-old drug, new use? Cimetidine antagonizes histamine's effects on some cancers and improves survival when given in the perioperative period. Nat Med 1: 1243-1244, 1995.

8. Svendsen LB, Ross C, Knigge U, Frederiksen HJ, Graversen P, Kjaergard J, Luke M, Stimpel H and Sparso BH: Cimetidine as an adjvant treatment in colorectal cancer. A double-blind, randomized pilot study. Dis Colon Rectum 38: 514-518, 1995.

9. Links M, Clingan PR, Phandke K, O'Baugh J, Legge J Adams WJ, Ross WB and Morris DL: A randomized trial of cimetidine with 5-fluorouracil and folinic acid in metastatic colorectal cancer. Eur J Surg Oncol 21: 523-525, 1995.
10. Tonnesen H, Knigge U, Bulow S, Damm P, Fisherman K, Hesselfeldt P, Hjortrup A, Pedersen VM, Siemssen OJ, Svensen LB and Christiansen PM: Effect of cimetidine on survival after gasric cancer. Lancet 2: 990-992, 1988.

11. Tozawa K, Okamoto T, Kawai N, Hashimoto Y, Hayashi Y and Kohri K: Positive correlation between sialyl Lewis X expression and pathologic findings in renal cell carcinoma. Kidney Int 67: 1391-1396, 2005.

12. Reynolds JL, Akhter J and Morris DL: In vitro effect of histamine and histamine $\mathrm{H} 1$ and $\mathrm{H} 2$ receptor antagonists on cellular proliferation of human malignant melanoma cell line. Melanoma Res 6: 95-99, 1996.

13. http://www.takara-bio.co.jp/realtime/prt_rs/search.php\#

14. Liotta LA: Tumor invasion and metastasis-role of the extracellular matrix: Rhoads memorial award Lecture. Cancer Res 46: 1-7, 1986.

15. Ehlers MR and Riordan JF: Membrane proteins with soluble counterparts: role of proteolysis in the release of transmembrane proteins. Biochemistry 30: 10065-10074, 1991.

16. Gearing AJ and Newman W: Circulating adhesion molecules in disease. Immunol Today 14: 506-512, 1993.

17. Takada A, Ohmori K, Takahashi N, Tsuyuoka K, Yago A, Zenita K, Hasegawa A and Kannagi R: Adhesion of human cancer cells to vascular endothelium mediated by a carbohydrate antigen, sialyl Lewis A. Biochem Biophys Res Commun 179: 713-719, 1991.

18. Takada A, Ohmori K, Yoneda T, Tsuyuoka K, Hasegawa A, Kiso $\mathrm{M}$ and Kannagi R: Contribution of carbohydrate antigens sialyl Lewis A and sialyl Lewis X to adhesion of human cancer cells to vascular endothelium. Cancer Res 53: 354-361, 1993.

19. Kannagi R: Carbohydrate-mediated cell adhesion involved in hematogenous metastasis of cancer. Glycoconj J 14: 577-584, 1997. 